\title{
Belt and Road (B\&R) initiative and its impact on financial research: introduction to the issue
}

\author{
Yan Dong ${ }^{*}$
}

*Correspondence:

ydong@swufe.edu.cn

Research Institute

of Economics

and Management \& Africa

Research Center, Faculty

of Business Administration,

Southwestern University

of Finance and Economics,

Chengdu, China
The Belt and Road (B\&R) Initiative, proposed by China in 2013, aims to boost regional economic cooperation and connecting China to Asia, Africa, and Europe. A total of 126 countries, including developed and developing nations, and 29 international organizations have signed cooperation documents with China on the initiative. In recent years, the world economy has witnessed repeated trials of strength between globalization and de-globalization. Nevertheless, B\&R Initiative has grown into one of the most promising platforms for international cooperation, forging a new pathway toward inclusive globalization. In the meantime, financial markets play an important role to economic development, especially for emerging markets, in which domestic investment, as well as foreign direct investment (FDI), is costly. Well-developed financial markets may help to fund investment in infrastructure, $R \& D$ etc., which ensure the successful operation of $B \& R$ Initiative.

This volume is the 27th issue of Financial Innovation (FIN), Volume 8, No. 3 (2021). In this issue, scholars from Asia, Africa and Europe have contributed their most up-todate studies mainly on developing nations that have joined in The Belt and Road Initiative. The eleven papers present us the contemporary theories and empirical findings on a range of topics such as commodity market, taxation policy, monetary policy, internet finance, asset pricing etc.

A famous Chinese poet from Tang Dynasty (618-907) once said in his poem: "A bosom friend afar brings a distant land near." We sincerely hope the papers here will encourage further academic investigations of Belt and Road Initiative's dynamics and help to address the tremendous opportunities and challenges facing business leaders and policy makers.

Articles included in the special issue are listed as follows:

The first paper, titled "Co-movement of commodity price indexes and energy price index: a wavelet coherence approach studies". This research studies the causal link between commodity price indexes in the global market. Understanding the evolution of commodity prices is important in assessing macroeconomic performance, especially for policy makers who are under heavy pressures of climate change.

The second paper, titled "Does access to credit reduce SMEs' tax avoidance? Evidence from a regression discontinuity design". It investigates the effect of targeted

(c) The Author(s), 2021. Open Access This article is licensed under a Creative Commons Attribution 4.0 International License, which permits use, sharing, adaptation, distribution and reproduction in any medium or format, as long as you give appropriate credit to the original author(s) and the source, provide a link to the Creative Commons licence, and indicate if changes were made. The images or other third party material in this article are included in the article's Creative Commons licence, unless indicated otherwise in a credit line to the material. If material is not included in the article's Creative Commons licence and your intended use is not permitted by statutory regulation or exceeds the permitted use, you will need to obtain permission directly from the copyright holder. To view a copy of this licence, visit http:// creativecommons.org/licenses/by/4.0/. 
reserve requirement ratio cuts (TRRRCs) on tax avoidance among small and micro enterprises (SMEs) in China. This paper finds TRRRCs significantly alleviate the financial constraints and cash dependence of SMEs and consequently reduce tax avoidance.

The third paper, titled "Voluntary tax compliance behavior of individual taxpayers in Pakistan". This individual tax compliance behavior is studied through the multi-perspective lenses of the theory of attribution, equity theory, expected utility theory, and social exchange theory. The results suggest that tax compliance simplicity has a larger impact on tax filing than perception about Government Spending and tax morale.

The fourth paper, titled "A study of the factors affecting mobile money penetration rates in the West African Economic and Monetary Union (WAEMU) compared with East Africa". Results suggest that in comparison to East Africa, the delay in the penetration of mobile money accounts observed in the WAEMU may be attributed to insufficient policies for increasing the awareness of the benefits of mobile financial services.

The fifth paper, titled "Are 'Internet + 'tactics the key to poverty alleviation in China's rural ethnic minority areas? Empirical evidence from Sichuan Province". In this research, results indicate that strengthening CII improves the PCIR and local economic growth, playing a key role in poverty alleviation. However, the stimulation of CII on LGGR and LGR wanes as time passes.

The sixth paper, titled "The impact of gross domestic product on the financing and investment efficiency of China's commercial banks". This study explores the efficiency of varies type of commercial banks in China. The results show that State owned commercial banks have the highest overall efficiency. However, all commercial banks need to focus on the efficiency of non-performing loans and return on capital.

The seventh paper, titled "A Markov regenerative process with recurrence time and its application". This study proposes a non-homogeneous continuous-time Markov regenerative process with recurrence times. Statistical tests confirm that the proposed model captures the rating dynamics better than the existing models, and the inclusion of recurrence times significantly impacts the transition probabilities.

The eighth paper, titled "A global perspective on macroprudential policy interaction with systemic risk, real economic activity, and monetary intervention". The study finds that global macroprudential policy leads the monetary policy, exhibiting a countercyclical pattern concerning industrial production. The latter has an inverse bidirectional linkage with systemic risk.

The ninth paper, titled "Do the RMB exchange rate and global commodity prices have asymmetric or symmetric effects on China's stock prices". This study explores the symmetric and asymmetric effects of the RMB exchange rate and global commodity prices on China's stock prices. The results suggest that increases in global commodity prices cause China's stock prices to decline sharply. In contrast, the same magnitude of decline in global commodity prices induces a smaller increase in China's stock prices.

The tenth paper, titled "A Predictive Indicator Using Lender Composition for Loan Evaluation in P2P Lending". Based on a dataset from Prosper, this research demonstrates that the maturity-based lender composition score can serve as an elective indicator for identifying loan quality and be included in other commonly used loan evaluation models for accuracy improvement. 
The eleventh paper, titled "What explains technical efficiency of banks in Tunisia? Evidence from two stage data envelopment analysis". This research found that the return on equity, the expense to income ratio, the loan to deposit ratio and the growth rate are insignificant to Tunisian banking technical efficiency. Reforms evolving bank governance and supervision coupled with public banks restructuring were found still not enough to raise the overall banking technical efficiency.

Authors' contributions

The author read and approved the final manuscript.

\section{Declarations}

Competing interests

The author declares that he has no competing interests.

Published online: 07 July 2021

\section{Publisher's Note}

Springer Nature remains neutral with regard to jurisdictional claims in published maps and institutional affiliations.

Submit your manuscript to a SpringerOpen ${ }^{\circ}$ journal and benefit from:

- Convenient online submission

- Rigorous peer review

- Open access: articles freely available online

High visibility within the field

Retaining the copyright to your article

Submit your next manuscript at $\boldsymbol{\nabla}$ springeropen.com 